\title{
Tropical Hardwood Hammocks in Florida 1
}

\section{Annisa Karim and Martin B. Main² \\ Introduction}

Tropical hardwood hammocks are one of many natural communities found in Florida, but one of the few that are characterized by tropical plants. The word "hammock" was first used by early inhabitants to mean a cool and shady place. Later, settlers of Florida used the word "hummock" to indicate areas that were slightly higher in elevation from the rest of the land. Today, the term hammock is used in Florida to describe forest habitats that are typically higher in elevation than surrounding areas and that are characterized by hardwood forests of broad-leaved evergreens. Tropical hardwood hammocks occur in south Florida and along the Florida coastlines where danger from frost is rare and tropical trees and shrubs common to the Caribbean islands (West Indian origin) are able to survive.

\section{Distribution}

Historically, tropical hardwood hammocks were found as far north as Cape Canaveral on Florida's east coast and up to the mouth of the Manatee River on the west coast. However, development pressure associated with growth of the South Florida human population has resulted in the conversion of many of these forests to urban and agricultural uses. Today, tropical hardwood hammocks occur primarily as remnant habitats in extreme South Florida and in small preserves along the Atlantic coast from Miami-Dade County north to Martin County.

\section{Flora of Tropical Hardwood Hammocks}

Tropical hardwood hammocks occur on patches of limestone, sand, and shell at elevations that usually do not flood. However, because these hammocks are typically densely vegetated, the conditions within the forests are moist (mesic). These forests are dominated by tropical trees and shrubs, most of which are evergreen or semi-deciduous, which means they hold leaves during most or all of the year. Tropical hardwood hammocks provide critical habitat for a number of plants whose northernmost portions of ranges extend into South Florida. These plants may be found in other tropical climates like the West Indies, but in the United States, they only occur in the tropical hardwood hammocks of South Florida. Consequently, many are listed as threatened or endangered in Florida. Bahama strongbark (Bourreria succulenta), buccaneer palm (Pseudophoenix sargentii), Florida boxwood (Schaefferia frutescens), lignum vitae (Guajacum

1. This document is WEC 181, one of a series of the Department of Wildlife Ecology and Conservation, Florida Cooperative Extension Service, Institute of Food and Agricultural Sciences (IFAS), University of Florida. Publication date: December 2004. Please visit the EDIS Web site at http://edis.ifas.ufl.edu.

2. Annisa Karim, Graduate Student, Wildlife Ecology and Conservation Dept., University of Florida/IFAS, Gainesville, FL; and Martin B. Main, Associate Professor, Wildlife Ecology and Conservation Dept., University of Florida/IFAS, Southwest Florida Research and Education Center, Immokalee, FL.

The Institute of Food and Agricultural Sciences (IFAS) is an Equal Employment Opportunity - Affirmative Action Employer authorized to provide research, educational information and other services only to individuals and institutions that function without regard to race, creed, color, religion, age, disability, sex, sexual orientation, marital status, national origin, political opinions or affiliations. For information on obtaining other extension publications, contact your county Cooperative Extension Service office. Florida Cooperative Extension Service / Institute of Food and Agricultural Sciences / University of Florida / Larry R. Arrington, Interim Dean 
sanctum), manchineel (Hippomane mancinella), and milkbark (Drypetes diversifolia) are all examples of tropical plants that are listed as endangered species by the state of Florida. Florida Statute 581.185 (Preservation of Native Flora of Florida) defines endangered plants as "species of plants native to the state that are in imminent danger of extinction within the state, the survival of which is unlikely if the causes of a decline in the number of plants continue." Although these plants are often described as being of West Indian origin, this simply means they are more common in the West Indies. They are native to Florida, which represents the northernmost extent of their geographical range.

Not all tropical species found in tropical hardwood hammocks are endangered. More common species include gumbo limbo (Bursera simaruba), black ironwood (Krugiodendron ferreum), inkwood (Exothea paniculata), lancewood (Ocotea coriacea), marlberry (Ardisia escallonoides), pigeon plum (Coccoloba diversifolia), satinleaf (Chrysophyllum oliviforme), poisonwood (Metopium toxiferum), and white stopper (Eugenia axillaris). Many of the trees and plants found in tropical hardwood hammocks provide useful products for humans. For example, the ability of the gumbo limbo to sprout roots and produce a new tree from a fallen branch has been used to create living fences of gumbo limbo trees. The wood of the lancewood was used to make fishing poles. The lignum vitae, which is sometimes called the "wood of life," is one of the densest woods available. Its density, oily resin, and fine texture made it historically important for the production of ship propeller shafts, bearings, caster wheels, rollers, and washers.

Whereas many plants in tropical hardwood hammocks are useful to humans, others can be harmful. For example, the poisonwood tree produces an oily resin that may cause severe skin irritation in humans. Poisonwood occurs in Florida's tropical hardwood hammocks and should be avoided.

\section{Fauna of Tropical Hardwood Hammocks}

Tropical hardwood hammocks provide habitat (food, water, shelter, and space) for a variety of

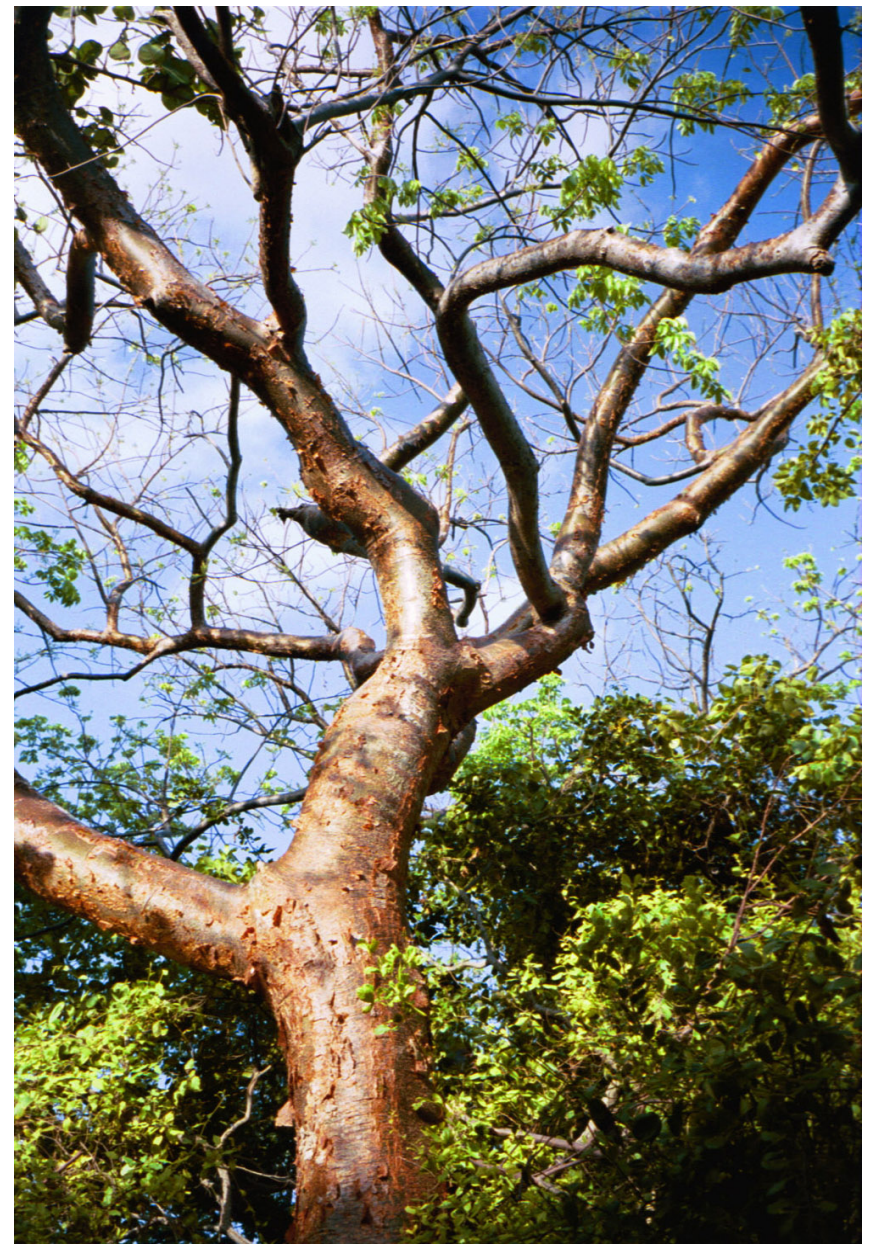

Figure 1. Gumbo limbo (Bursera simaruba). Credits: UF/IFAS

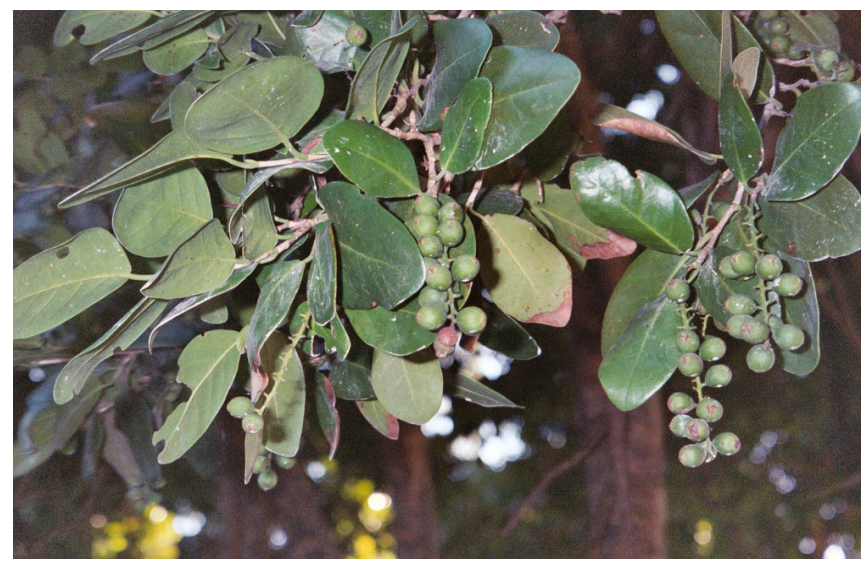

Figure 2. Pigeon plum (Coccoloba diversifolia). Credits: UF/IFAS

wildlife. There are very few animals that live exclusively in hammocks, but many animals take advantage of the relatively cool interior and slightly higher elevation provided by hammocks. Many birds use hammocks, including migratory species. Many of the trees that occur in tropical hardwood 


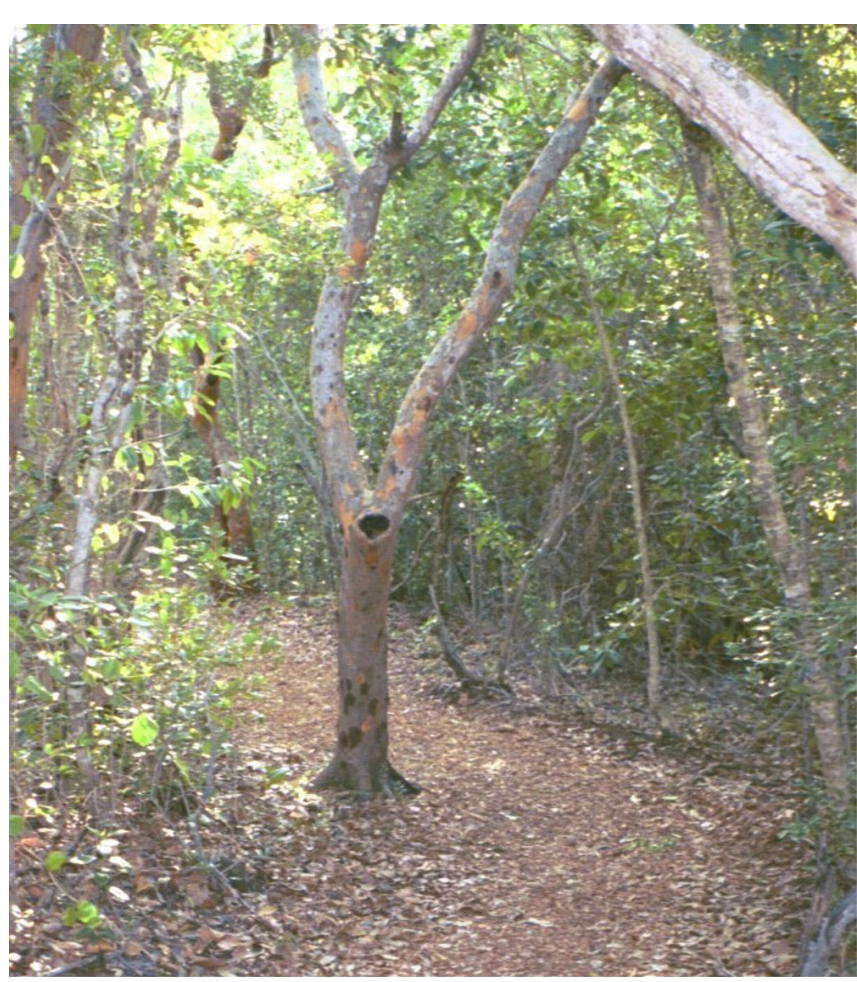

Figure 3. Poisonwood (Metopium toxiferum). Credits: UF/IFAS

hammocks produce fruit that both resident and migratory birds depend upon. In particular, these areas may provide critical habitat where migratory birds can stop, eat, and rest before they continue their migration. Examples of migratory birds reported to use tropical hardwood hammocks include the endangered Kirtlands warbler (Dendroica kirtlandii), ovenbird (Seiurus aurocapillus), solitary vireo (Vireo solitarius), and gray kingbird (Tyrannus dominicensis). Some birds also nest in these forests, such as the threatened white-crowned pigeon (Columba leucocephala), black-whiskered vireo (Vireo atiloquus), mangrove cuckoo (Cocczyus minor), great crested flycatcher (Myiarchus crinitus), cardinal (Cardinalis cardinalis), red-bellied woodpecker (Melanerpes carolinus), pine warbler (Dendroica pinus), white-eyed vireo (Vireo griseus), and carolina wren (Thryothorus ludovicianus).

In addition to birds, many other animals rely on tropical hardwood hammocks as an integral part of their habitat, including several endangered species. The Florida panther (Puma concolor coryi), Florida Key deer (Odocoileus virginianus clavium), Key Largo cotton mouse (Peromyscus gossypinus allapaticola), Key Largo woodrat (Neotoma floridana smallii), Florida mastiff bat (Eumops glaucinus floridanus), Stock Island tree snail (Orthalicus reses), and Schaus swallowtail butterfly (Heraclides aristodemus ponceanus) are all endangered species known to use these habitats.

\section{Future of Tropical Hardwood Hammocks: A Conservation Challenge}

Conserving Florida's remaining tropical hardwood hammocks will benefit the many different types of wildlife that use and depend on these habitats. Preserving these remaining habitats may be especially important for species that are endangered or migratory. Saving these natural areas is also good for Florida's economy. Tourism is the state's number one industry. During 1994, the Florida Department of Environmental Protection reported that birdwatchers accounted for $\$ 477$ million in retail sales, creating 13,880 jobs related to bird watching and an $\$ 897$ million economic impact in Florida. The US Fish and Wildlife Service reported that, during 2001, visitors and residents of Florida spent more than $\$ 1.5$ billion on activities associated with wildlife viewing. Consequently, conserving habitats that are important for wildlife, such as tropical hardwood hammocks, makes good economic sense.

The challenges to conserving these habitats are considerable. The population of Florida is growing at a tremendous rate, with $900-1,000$ people moving to the state every day. Although most remaining tropical hardwood hammocks north of the Florida Keys are in public ownership, much of the remaining hammocks in the Keys are privately owned. The conservation challenge for the future will be to identify innovative approaches for conserving tropical hardwood hammocks and restoring and creating new hammocks to provide for the plants and wildlife that depend on them. Information on conservation options for private landowners in Florida is available on the UF/IFAS EDIS Web site at http://edis.ifas.ufl.edu/UW195 and http://edis.ifas.ufl.edu/UW194. 


\section{Additional Sources of Information}

Atlas of Florida Vascular Plants. Institute for Systemic Botany. http://www.plantatlas.usf.edu/.

Main, M. B., M. E. Hostetler, and A. Karim. 2003. Evaluating Private Lands for Conservation of Wildlife. University of Florida Cooperative Extension Service Document WEC 164. 2 pp. University of Florida, UF/IFAS Extension Digital Information Source (EDIS) Database. http://edis.ifas.ufl.edu/UW195.

Main, M. B., A. Karim, and M. E. Hostetler. 2003. Conservation Options for Private Landowners in Florida. University of Florida Cooperative Extension Service Circular 1441. 10 pp. University of Florida, UF/IFAS Extension Digital Information Source (EDIS) Database. http://edis.ifas.ufl.edu/UW194.

Platt, W. J., and M. W. Schwartz. 1990. Temperate hardwood forests. Pages 194-229, in Myers, R. L. and J. J. Ewel (editors), Ecosystems of Florida. University of Central Florida Press, Orlando, Florida.

Southwick, R. and T. Allen. 2003. The 2001 Economic Benefits of Watchable Wildlife Recreation in Florida. http://myfwc.com/viewing/articles/wwecon2001.pdf.

United States Fish and Wildlife Service. 1999. South Florida multi-species recovery plan. U.S.F.W.S. Southeast Region. http://verobeach.fws.gov/programs/Recovery/ vbms5.html. 